\title{
THE PASSAGE OF FLUID AND PROTEIN THROUGH THE HUMAN CAPILLARY WALL DURING VENOUS CONGESTION
}

\author{
By EUGENE M. LANDIS, L. JONAS, 1 M. ANGEVINE, AND W. ERB
}

(From the Robinette Foundation and William Pepper Laboratory of Clinical Medicine, Hospital of the University of Pennsylvania, Philadelphia)

(Received for publication March 22, 1932)

It has been demonstrated in normal human subjects by several methods that during venous congestion fluid is filtered from the blood into the tissue spaces. This passage of fluid through the capillary wall has been identified by comparing blood samples removed during normal circulation and during venous congestion (Schultz and Wagner (1909); Rowe (1915); Dautrebande, Davies and Meakins (1923); Peters, Eisenman and Bulger (1925)). It has been observed also that when the venous pressure in the legs is increased by quiet standing, fluid is filtered from the blood stream with a consequent reduction in circulating blood volume (Thompson, Thompson and Dailey (1928); Waterfield (1931)). The filtration produced by measured grades of venous congestion has been measured also by plethysmographic methods in which the accumulation of fluid in the tissue spaces was estimated by measuring the increase in limb volume (Drury and Jones (1927); Krogh, Landis and Turner (1932)).

The capillary wall has usually been regarded as relatively impermeable to proteins (Krogh (1929); Thompson, Thompson and Dailey (1928); Krogh, Landis and Turner (1932)). Waterfield (1931) however, differed from Thompson, Thompson and Dailey in finding that during standing the blood lost not only fluid but also a significant amount of protein. Drinker and his co-workers (1931) have called attention to the high concentration of protein often found in lymph. Maintaining that tissue fluid and lymph are identical, they regard the capillary wall as everywhere quite permeable to protein even under normal conditions.

A retrograde movement of protein from the tissue spaces through the capillary wall into the blood during venous stasis has been described by Plass and Rourke (1927). They found that during venous congestion the blood proteins were always increased by a greater percentage than was cell volume. This was believed to indicate that during venous congestion proteins must pass from the tissue spaces into the blood stream. It will be shown below that the direct comparison of percentage increase in cell volume with the percentage increase in plasma proteins is unjusti-

1 Woodward Fellow in Physiological Chemistry. 
fied. Actually their figures show loss of both fluid and protein from the blood stream.

The amount of tissue fluid accumulating in the arm during mild venous congestion (Krogh, Landis and Turner (1932)) seemed great enough to produce measurable changes in the fluid content of the blood. Assuming that the fluid is lost chiefly from the plasma, the amount of capillary filtrate per $100 \mathrm{cc}$. of blood can be calculated from the cell volume of normal blood and the apparent increase in the cell volume of the blood after passage through the congested vessels.

If the capillary wall were totally impermeable to colloids the protein content of the blood would be increased in proportion to the reduction in plasma volume. However, in computations involving changes in cell volume and plasma proteins, allowance must be made for the fact that the cell volume is measured in volumes per cent of blood (i.e. plasma plus cells) while blood proteins are measured in terms of percentage of plasma. Knowing the change in cell volume produced by stasis and the protein percentage of normal blood, it is possible to calculate the increase in plasma protein to be expected if no protein were lost in the capillary filtrate. The difference between the calculated amount of protein and the amount determined by analysis indicates the amount of protein lost in the capillary filtrate.

From a recalculation of the data reported by Plass and Rourke (1927), and from our own findings, it appears that high grades of venous congestion caused the filtration of relatively large amounts of fluid containing a high percentage of the three protein fractions present in blood plasma. Very low congestion pressures were accompanied by the filtration of small amounts of fluid without detectable loss of protein, but the volume changes were probably too small to permit any certain conclusion concerning protein. Finally, in two patients edema fluid largely produced by, and collected during, venous stasis contained 0.39 and 0.09 per cent protein.

\section{METHODS}

The blood studies were made in normal male subjects or in male patients hospitalized for minor maladies unrelated to the circulatory system. Their blood pressures were not in any instance significantly abnormal; their ages ranged from 24 to 40 years.

In order to avoid postural changes in fluid balance the subjects reclined 30 minutes before the venous congestion was started. The forearms were supported on sandbags at the side of the body, so that the upper (flexor) surfaces were level with the clavicles. The skin temperature of each forearm was measured at five-minute intervals by means of thermal junctions held, by a single layer of surgeon's plaster, in contact with the skin on the flexor surface of the forearm midway between wrist and elbow. Venous pressure was elevated by means of Riva Rocci armlets, $12 \mathrm{~cm}$. wide and $50 \mathrm{~cm}$. long, wrapped around the arm well above the elbow.

At the end of the thirty minute rest period the armlets were inflated simultaneously and suddenly from reservoirs connected with manometers. On the 
control side the armlet pressure was $9 \mathrm{~mm}$. $\mathrm{Hg}$, a pressure which, though enough to distend the veins slightly, did not produce measurable filtration in plethysmographic observations (Krogh, Landis and Turner (1932)). The pressure in the other armlet was raised to $20,40,60$, or $80 \mathrm{~mm}$. $\mathrm{Hg}$ in the experimental observations and to $9 \mathrm{~mm}$. $\mathrm{Hg}$ in three control observations. The subjects were cautioned against moving the arm or forearm during the congestion period.

When venous pressure had been elevated for a period of 30 minutes samples of venous blood were removed simultaneously from each arm, approximately $30 \mathrm{cc}$. of blood being collected in a syringe containing $20 \mathrm{mgm}$. of dry heparin. The armlets were deflated only after the blood samples were removed. The blood was agitated in the syringes for fifteen minutes to dissolve the heparin and to mix it thoroughly with the blood. The samples were then transferred to test tubes in which the gentle agitation was continued while small amounts were removed for determinations of cell volume, hemoglobin and erythrocyte counts.

Hematocrit determinations were carried out immediately, usually in triplicate, using tubes having an inside diameter of $2 \mathrm{~mm}$. and a length of $12 \mathrm{~cm}$. A certain number of determinations were also made with Wintrobe hematocrit tubes. The filled tubes were rotated for 30 minutes at a speed of 3000 r.p.m.

PROTOCOL 1

Venous congestion of $80 \mathrm{~mm}$. $\mathrm{Hg}$.

Subject L. December 8, 1931. Room temperature $24.2^{\circ} \mathrm{C}$.

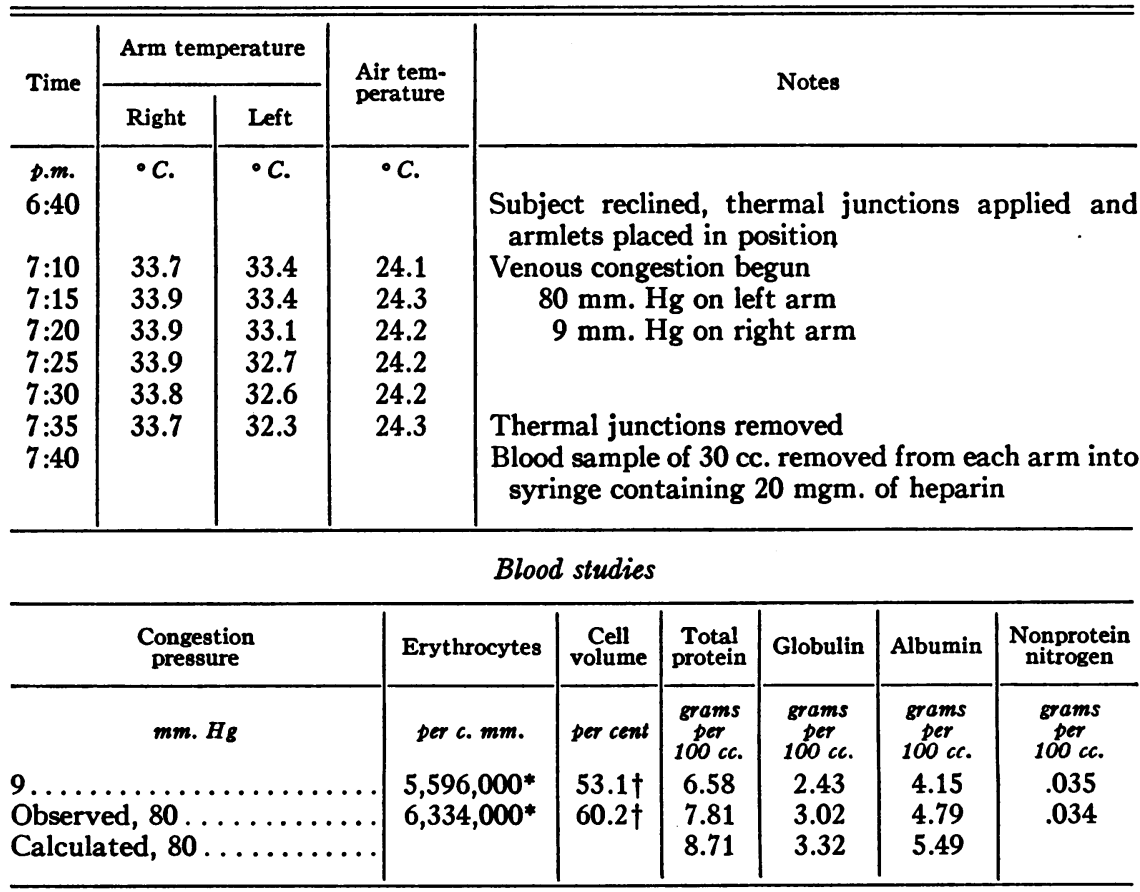

* Average of 8 counts.

$\dagger$ Average of 3 tubes. 
In certain observations 3 to 5 erythrocyte counts were made on each sample by each of two observers, the results being averaged to determine the percentage increase in erythrocytes produced by stasis. Hemoglobin determinations were made according to the method of Dreyer, Bazett and Pearce (1920). Of the blood $0.1 \mathrm{cc}$. was diluted with $19.9 \mathrm{cc}$. of 0.9 per cent sodium chloride solution. This suspension of cells was hemolyzed with saponin and the depth of color in the two specimens was compared by colorimeter, using diffuse daylight. The blood from the control side was taken as 100 per cent and only the relative increase was determined. Plasma proteins were estimated according to the method of Howe (1921). When the changes in total protein were conspicuously large, the plasma proteins were separated into globulin and albumin fractions, the former containing also fibrinogen.

Protocols 1 and 2 show the details of experiments at congestion pressures of $80 \mathrm{~mm} . \mathrm{Hg}$ and $40 \mathrm{~mm} . \mathrm{Hg}$ respectively.

PROTOCOL 2

Venous congestion of $40 \mathrm{~mm}$. $\mathrm{Hg}$.

Subject $R$. December 29, 1931. Room temperature $24.5^{\circ} \mathrm{C}$.

\begin{tabular}{|c|c|c|c|c|c|c|c|}
\hline \multirow{2}{*}{ Time } & \multicolumn{2}{|c|}{ Arm temperature } & \multirow{2}{*}{$\begin{array}{l}\text { Air tem- } \\
\text { perature }\end{array}$} & \multirow{2}{*}{\multicolumn{4}{|c|}{ Notes }} \\
\hline & Right & Left & & & & & \\
\hline $\begin{array}{l}p . m . \\
6: 39 \\
7: 09 \\
7: 14 \\
7: 19 \\
7: 24 \\
7: 29 \\
7: 34 \\
7: 39\end{array}$ & $\begin{array}{l}34.4 \\
34.4 \\
34.3 \\
34.3 \\
34.2 \\
34.1\end{array}$ & $\begin{array}{l}33.7 \\
33.0 \\
33.0 \\
32.9 \\
32.9 \\
32.7\end{array}$ & $\begin{array}{l}24.8 \\
24.8 \\
24.2 \\
24.3 \\
24.3 \\
24.3\end{array}$ & \multicolumn{4}{|c|}{$\begin{array}{l}\text { Subject reclined, thermal junctions applied and } \\
\text { armlets placed in position } \\
\text { Venous congestion begun } \\
\quad 40 \mathrm{~mm} \text {. Hg on left arm } \\
\quad 9 \mathrm{~mm} . \mathrm{Hg} \text { on right arm } \\
\text { Thermal junctions removed } \\
\text { Blood sample of } 30 \mathrm{cc} \text {. removed from each arm into } \\
\text { syringe containing } 20 \mathrm{mgm} \text {. of heparin }\end{array}$} \\
\hline \multicolumn{8}{|c|}{ Blood studies } \\
\hline \multicolumn{3}{|c|}{$\begin{array}{c}\text { Congestion } \\
\text { pressure }\end{array}$} & \multicolumn{2}{|c|}{ Hemoglobin } & Cell volume & Total protein & $\begin{array}{c}\text { Nonprotein } \\
\text { nitrogen }\end{array}$ \\
\hline $\begin{array}{l}9 . \ldots \\
\text { Observ } \\
\text { Calcul }\end{array}$ & 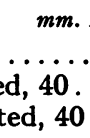 & $\begin{array}{l}\ldots \ldots \\
\cdots \\
\ldots \ldots\end{array}$ & \multicolumn{2}{|c|}{$\begin{array}{c}\text { per cent initial } \\
100.0 \\
106.3\end{array}$} & $\begin{array}{r}\text { per cent } \\
38.8^{*} \\
41.0^{*}\end{array}$ & $\begin{array}{c}\text { grams per } 100 \text { cc. } \\
6.17 \\
6.80 \\
6.79\end{array}$ & $\begin{array}{c}\text { grams per } 100 \mathrm{cc} . \\
.028 \\
.026\end{array}$ \\
\hline
\end{tabular}

* Average of two tubes.

\section{METHODS OF CALCULATION}

To calculate the loss of fluid per $100 \mathrm{cc}$. of blood from hematocrit determinations requires the assumption that the fluid is lost entirely from the plasma, and that in the concentration of the blood the absolute size of the cellular elements has not changed significantly. Dautrebande, Davies and Meakins (1923) describe a single observation in which stasis increased the hematocrit reading by a smaller percentage than the oxygen capacity and the hemoglobin 
content. They calculated that 20 per cent of the fluid lost by the blood must have been removed from the erythrocytes and 80 per cent from the plasma. Peters, Eisenman and Bulger (1925), on the contrary, report two observations in which the application of a tourniquet to the arm for five minutes increased the oxygen capacity by 20.6 and 23.3 per cent while the cell volume was increased by 19.9 and 25.5 per cent respectively. They conclude that the fluid lost from the blood during stasis is removed almost entirely from the plasma. A similar finding is reported by Peters (1924).

Van Slyke, Wu and McLean (1923) observed that as blood changes from the arterial to the venous state there is a slight but definite increase in cell volume. In venous congestion the increase in $\mathrm{CO}_{2}$ tension of the blood tends to increase the cell volume which must, of course, affect the hematocrit readings. The effect is to some extent counteracted by the increased oxygen unsaturation. This change, though present, is small, amounting to only $0.6 \mathrm{vol}$ umes per cent for a change of $30 \mathrm{~mm}$. in $\mathrm{CO}_{2}$ tension even when oxygen-saturation is unchanged (Eisenman, Bulger and Peters (1926)). It did not seem necessary nor advisable to collect the blood under oil since the loss of $\mathrm{CO}_{2}$ would only diminish any change of cell volume that had resulted from the accumulation of $\mathrm{CO}_{2}$ which occurred during stasis.

During venous congestion the concentration of the plasma protein increases. If the wall of the erythrocytes were impermeable to protein alone this change might be expected to diminish cell volume. Van Slyke, Wu and McLean, however, on the assumption that the membrane of the erythrocyte is impermeable to proteins and to the inorganic cations, regarded the osmotic effects of the plasma proteins as a negligible factor in the movement of water between the erythrocytes and plasma because the effective osmotic pressure of the plasma can be modified very little by change in the plasma protein percentage.

Sudden variations in the number of red cells per unit volume of blood have been described by Lamson, Abt, Oosthuisen and Rosenthal (1923). Since the arterial blood entering both arms must have the same composition, systemic variations in red cell number would be present in both arms equally. To avoid the effects of these changes blood samples were removed from the contro. and the experimental arms simultaneously and at approximately the same ratel In this way each experiment included its own control. The possible effects of systemic variations in red cell number on the comparison of unconcentrated and concentrated blood were thereby avoided.

In all the observations here reported the hematocrit readings were matched with either red cell counts or with hemoglobin determinations to identify any significant error which might arise from changes in absolute cell volume. No consistent differences were found (Table 1) between the two series of figures. Under the conditions of these observations, therefore, it seemed justifiable to calculate water loss from the changes in hematocrit readings, assuming that there was no change in the water content of the erythrocytes. Thus, if 100 cc. of unconcentrated blood from the control arm is compared with concentrated blood removed simultaneously from the other arm certain relations will hold. If the percentile cell volume of the normal blood is $C_{1}$ and that of the concentrated blood $C_{2}$ while the loss of water or volume from $100 \mathrm{cc}$. of initially unconcentrated blood is $x$, then

$$
x=100-100 \frac{C_{1}}{C_{2}} .
$$

If the capillary wall has allowed no plasma protein to pass during the process of concentration of the blood, the absolute amount of plasma protein will be 
the same, but the percentage will be increased in proportion to the concentration of the plasma fraction of the blood. If the protein percentage of the normal plasma is $P r_{1}$ and that of the concentrated plasma $P r_{2}$, while $P l_{1}$ and $\mathrm{Pl}_{2}$ represent the plasma volume of normal and concentrated blood respectively per $100 \mathrm{cc}$. of initially unconcentrated blood, then, if no gain or loss of water by the cells is postulated, $P l_{2}=P l_{1}-x$, and

$$
P r_{2}=P r_{1} \frac{P l_{1}}{P l_{1}-x} \text {. }
$$

By comparing the calculated protein percentage, $\mathrm{Pr}_{2}$, with that actually observed, $\mathrm{Pr}_{2}{ }^{\prime}$, the loss of protein may be detected. The actual amount of protein lost by the plasma from an initial volume of $100 \mathrm{cc}$. of blood, $\Delta \overline{P r}$, can be estimated from the observed protein percentages.

$$
\Delta \overline{P r}=P r_{1} \times \frac{P l_{1}}{100}-P r_{2}{ }^{\prime} \times \frac{P l_{1}-x}{100} .
$$

Knowing the amount of fluid $(x)$ which left the plasma and the simultaneous loss of protein $(\Delta \overline{P r})$ the percentage of protein in the capillary filtrate can be estimated.

\section{OBSERVATIONS}

The results are collected in Table 1 . Room temperature was kept between 22.6 and $25.9^{\circ} \mathrm{C}$. to avoid marked cooling of the exposed arms during the observation. The average arm temperature varied between 35.1 and $31.6^{\circ}$. Skin temperature fell gradually when higher grades of venous congestion were used; this fall was never more than $1.2^{\circ} \mathrm{C}$. and was usually less than $1.0^{\circ} \mathrm{C}$.

\section{(A). The loss of fluid from the blood during venous congestion}

With a venous pressure of $80 \mathrm{~mm}$. $\mathrm{Hg}$ the relative cell volume was increased by 13.4 to 24.2 per cent while the hemoglobin and red cells were increased by 13.1 to 22.9 per cent. These changes indicate a loss of fluid amounting to between 11.9 and $19.5 \mathrm{cc}$. from $100 \mathrm{cc}$. of whole blood.

With a venous pressure of $60 \mathrm{~mm}$. $\mathrm{Hg}$ relative cell volume was increased by 7.8 to 9.7 per cent while red cells and hemoglobin were increased by 7.3 to 10.8 per cent, indicating that the fluid lost amounted to between 7.2 and $8.9 \mathrm{cc}$. from $100 \mathrm{cc}$. of whole blood.

With a venous pressure of $40 \mathrm{~mm}$. $\mathrm{Hg}$ the changes were still smaller and, due probably to the relatively greater error, more variable. Relative cell volume increased by 1.9 to 5.7 per cent while the hemoglobin increased by 0.9 to 6.3 per cent, indicating that the fluid loss amounted to between 1.9 and $5.6 \mathrm{cc}$. from $100 \mathrm{cc}$. of whole blood.

With a venous pressure of $20 \mathrm{~mm}$. $\mathrm{Hg}$ there was a measurable change in two of three experiments. Relative cell volume increased by 1.0 to 2.6 per cent and the hemoglobin by 0.7 and 1.6 per cent. The loss of fluid amounted to between 0 and $2.3 \mathrm{cc}$. from $100 \mathrm{cc}$. of whole blood. 
In three observations in which venous pressure was $9 \mathrm{~mm} . \mathrm{Hg}$ in both arms there was no change in the relative cell volume in two experiments, and a small but unimportant change in the third.

Plass and Rourke (1927) have reported a series of observations in which hematocrit readings were made on blood drawn with and without venous congestion. Those experiments in which measured grades of venous congestion were used have been collected in Table 2 to show fluid loss for comparison with our own data. Venous congestion of $100 \mathrm{~mm}$. $\mathrm{Hg}$ for 15 to 22 minutes was accompanied by a loss of between 18.9 and $29.3 \mathrm{cc}$. per $100 \mathrm{cc}$. of blood. At $90 \mathrm{~mm}$. $\mathrm{Hg}$ the loss was distinctly less, amounting to between 12.5 and $15.4 \mathrm{cc}$. per $100 \mathrm{cc}$. of blood. One observation at a venous pressure of $80 \mathrm{~mm}$. $\mathrm{Hg}$ showed a loss of $7.9 \mathrm{cc}$. after 26 minutes. The two series of observations indicate that the loss of fluid increases as the venous pressure rises.

The relationship between fluid loss and venous pressure is shown in Figure 1. It is apparent that the loss of fluid is not directly propor-

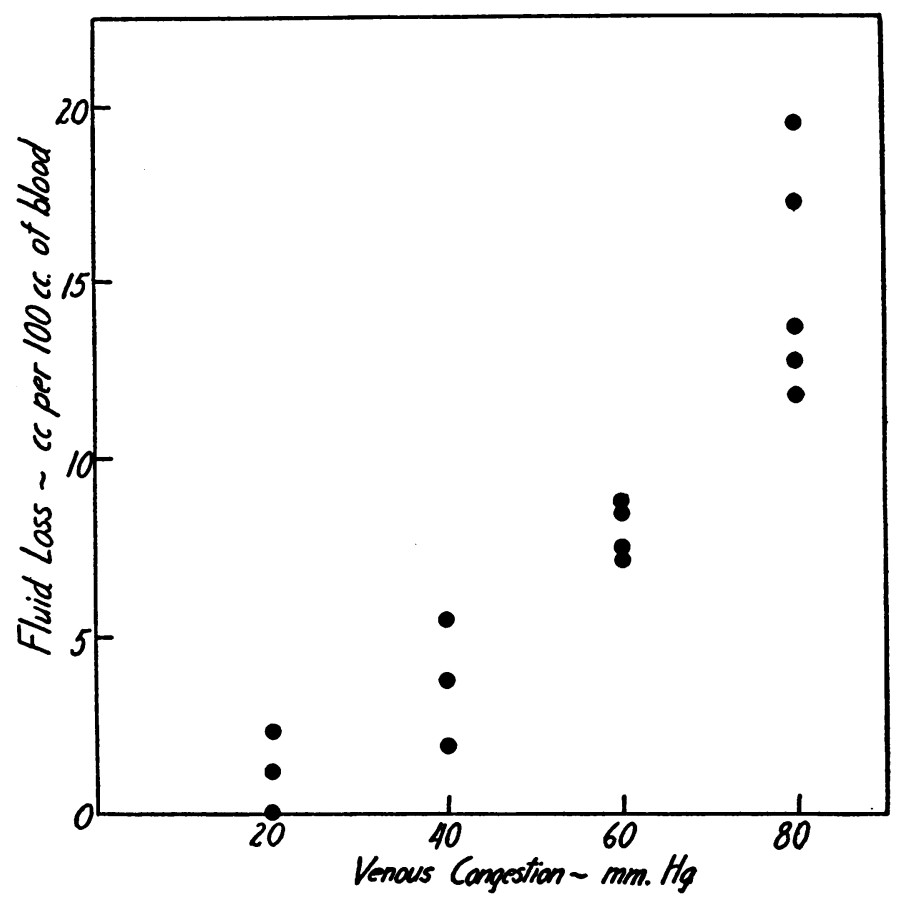

Fig. 1. Chart Showing Relationship Between Venous Congestion and LosS OF Fluid FROM THE BLOOD

tional to the level of venous pressure. The reason for this is discussed below. 


\begin{tabular}{|c|c|c|c|c|c|c|c|c|c|c|}
\hline & 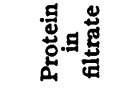 & 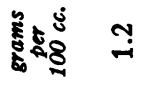 & $\stackrel{\Upsilon}{\sim}$ & $\stackrel{\infty}{i}$ & $\overrightarrow{0}$ & $\stackrel{m}{i}$ & $\tilde{0}$ & $\stackrel{0}{0}$ & $\ddot{m}$ & $\overline{0}$ \\
\hline & 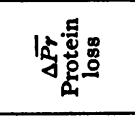 & 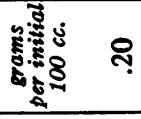 & $=$ & חె? & $\overline{0}$ & $\mathbb{Z}$ & ๕. & 8 & ชั & के \\
\hline & 超罡 & نั & $\vec{m}$ & $\stackrel{9}{\Rightarrow}$ & $\stackrel{a}{\sim}$ & $\stackrel{n}{a}$ & $\stackrel{0}{\infty}$ & $\stackrel{+}{\circ}$ & 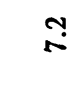 & $\stackrel{\infty}{\infty}$ \\
\hline & 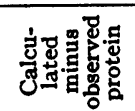 & हैं & $\stackrel{\infty}{\substack{0 \\
0}}$ & \& & $\ddot{0}$ & $\stackrel{\infty}{=}$ & $\frac{H}{0}$ & 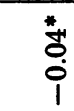 & $\underset{0}{0}$ & ชิ \\
\hline & R. & 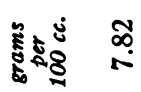 & ח్ֶ & $\underset{\infty}{F}$ & $\underset{\infty}{\infty}$ & 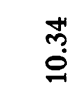 & $\begin{array}{l}0 \\
\infty \\
\infty\end{array}$ & ঙฺָ & 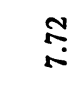 & $\stackrel{\infty}{n}$ \\
\hline & 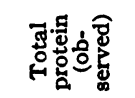 & بّ̂ & $\frac{9}{4} \frac{1}{0}$ & مْ & సีః & $\begin{array}{l}-10 \\
0 \\
0 \\
0\end{array}$ & ○ั & 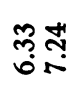 & 实 & స్ํำ \\
\hline & 递 & 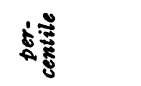 & & & & $\stackrel{\text { ते }}{\text { }}$ & & & $\underset{\infty}{+1}$ & กี \\
\hline$-\frac{\overrightarrow{8}}{8}$ & 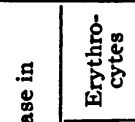 & 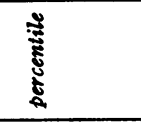 & $\stackrel{n}{\sharp}$ & $\vec{m}$ & $\begin{array}{l}0 \\
\end{array}$ & & $\stackrel{?}{r}$ & $\stackrel{\infty}{0}$ & & \\
\hline 总 & 总 & 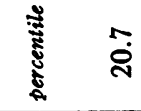 & ติ & $\stackrel{\sharp}{\dddot{m}}$ & $\stackrel{g}{+}$ & ָั & $\hat{a}$ & $\underset{\infty}{\circ}$ & $\stackrel{\infty}{\sim}$ & $a$ \\
\hline & 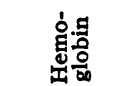 & $\begin{array}{l}\text { है. } \\
\text { t. }\end{array}$ & & & & 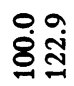 & & & 우유. & 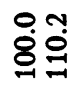 \\
\hline & 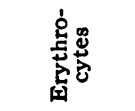 & 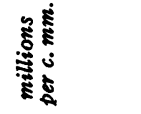 & 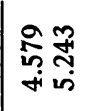 & 官 & 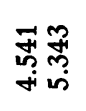 & & 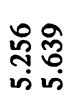 & 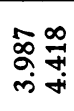 & & \\
\hline & 递 & 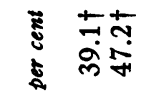 & พั่ & min & 我 & 구 in & 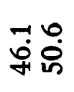 & 舫 & ํㅜ & 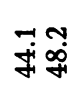 \\
\hline & 旡导 & ن & जे & लై & હૅ. & 亗 & 물 & 울요 & 苛苛 & 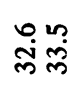 \\
\hline & 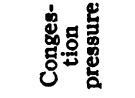 & : & $a_{\infty}$ & a \& & ๑ঃ & a\& & 98 & 98 & $a_{8}$ & 08 \\
\hline & 量势 & ن & $\stackrel{\infty}{\tilde{n}}$ & ָี & $\ddot{\sim}$ & 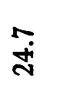 & సે & ஸุ & ํㅗㄱ & $\stackrel{\infty}{\stackrel{i}{i}}$ \\
\hline & 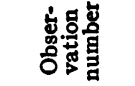 & $N$ & $m$ & $H$ & in & $\stackrel{0}{\circ}$ & 0 & - & $\infty$ & $\approx$ \\
\hline
\end{tabular}




\begin{tabular}{|c|c|c|c|c|c|c|c|c|c|c|}
\hline 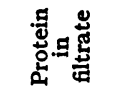 & हैं & $\stackrel{0}{0}$ & 웅 & & & & & & & \\
\hline 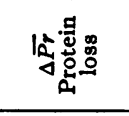 & 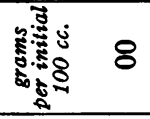 & 8 & 8 & & & & & & & \\
\hline 弮品 & نه & $\stackrel{\infty}{m}$ & $\stackrel{9}{-}$ & $\leftrightarrows$ & $\ddot{\sim}$ & $\stackrel{\circ}{0}$ & 웅 & $\stackrel{\circ}{0}$ & $\stackrel{*}{*}$ & \\
\hline 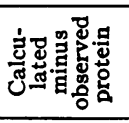 & 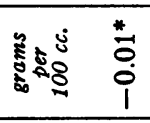 & 華 & $\begin{array}{l}* \\
\text { in } \\
i \\
i \\
\end{array}$ & & & & $\stackrel{n}{0}$ & $\stackrel{\circ}{\circ}$ & $\begin{array}{l}\hat{0} \\
0\end{array}$ & \\
\hline 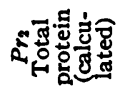 & : & $\stackrel{7}{=}$ & 疍 & & & & $\stackrel{?}{\sharp !}$ & $\vec{\infty}$ & $\stackrel{8}{\circ}$ & \\
\hline 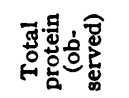 & 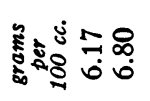 & 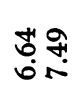 & นึ้ & & & & 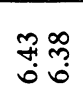 & D: & $=\frac{9}{1}$ & \\
\hline 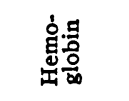 & ڤే & $\stackrel{n}{+}$ & $\stackrel{a}{0}$ & $\tilde{0}$ & $\stackrel{0}{\rightarrow}$ & & $\ddot{0}$ & ָ̊ & $\ddot{i}_{i}^{n}$ & \\
\hline 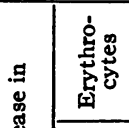 & 苋 & & & & & & & & & \\
\hline 总 & 䒕 & ले & $\stackrel{9}{-}$ & $\stackrel{\circ}{\circ}$ & $\stackrel{\circ}{i}$ & $\stackrel{\circ}{0}$ & $\stackrel{\circ}{0}$ & $\stackrel{0}{0}$ & 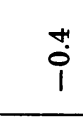 & 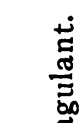 \\
\hline 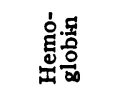 & 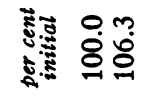 & 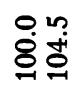 & 영 & 웅 & 迥 & & 웅 & 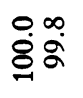 & ஜ் & 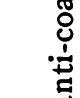 \\
\hline 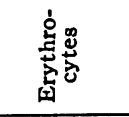 & : & & & & & & & & & \\
\hline 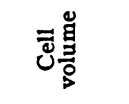 & 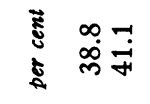 & $\begin{array}{l}n+4 \\
\infty \\
\infty \\
\infty\end{array}$ & $\begin{array}{l}0 \\
\dot{9}+\dot{\square}\end{array}$ & ํㅜㅁ & 亲苛 & 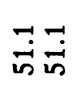 & $\hat{q}$ & 䇣尔 & 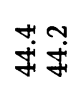 & 离蓠 \\
\hline 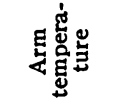 & ن & लें & 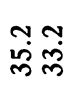 & సָ & 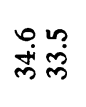 & חָ & ले & 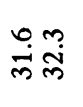 & $\ddot{m} \ddot{m}$ & 范 \\
\hline 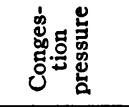 & $\stackrel{\infty}{ \pm}$ aq & ag & 와 & a요 & a요 & a్ㅛ & $a a$ & a a & $a a$ & 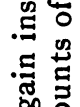 \\
\hline 造密 & ن & $\stackrel{\text { ㅁ }}{\text { i }}$ & นึ่ & $\stackrel{\circ}{\stackrel{\sim}{N}}$ & $\underset{\sim}{\sim}$ & $\stackrel{\text { ํ. }}{\text { i }}$ & $\stackrel{\circ}{\text { N }}$ & $\stackrel{\circ}{2}$ & $\stackrel{\infty}{\stackrel{\infty}{i}}$ & 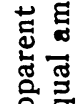 \\
\hline 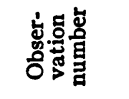 & $a$ & 으 & $\cong$ & $\stackrel{\infty}{\sim}$ & 2 & 유 & $m$ & $\Xi$ & 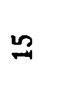 & 4 \\
\hline
\end{tabular}




\section{(B) The passage of protein through the capillary wall during venous congestion}

The observations on the influence of venous congestion on the plasma protein percentage are shown in Table 1. The total protein content of the blood removed from the control arms (venous pressure $9 \mathrm{~mm} . \mathrm{Hg}$ ) varied between 5.61 and 7.13 per cent. In the same column below each normal figure is shown the protein content of the blood removed simultaneously from the other arm in which venous pressure was elevated to $80,60,40,20$, or $9 \mathrm{~mm}$. $\mathrm{Hg}$. For purposes of comparison in the next column are given figures which represent the concentration of protein which, if the capillary walls were impermeable to protein, should have been produced by the fluid loss observed.

In one of the five experiments at $80 \mathrm{~mm}$. $\mathrm{Hg}$ pressure the observed and calculated protein concentrations agreed, indicating that little or no protein had been lost. In the remaining four experiments the calculated protein content was greater than the observed protein content by 0.38 to 1.18 per cent indicating a significant loss through the capillary wall.

Knowing the amount of plasma, the apparent loss of protein from 100 cc. of blood was computed according to the method described above. Dividing the protein loss (grams) by the amount of filtrate formed simultaneously provided a rough estimate of the protein percentage of the capillary filtrate. With a venous pressure of $80 \mathrm{~mm} . \mathrm{Hg}$ the filtrate appeared to contain between 0.1 and 2.8 per cent protein, indicating that under those conditions the capillary wall is far from impermeable to protein.

A venous pressure of $60 \mathrm{~mm}$. $\mathrm{Hg}$ produced a significant loss of protein in one experiment (number 6); the discrepancy between the observed and calculated protein percentage amounted to 0.14 per cent, corresponding to 0.7 per cent protein in the $8.9 \mathrm{cc}$. of filtrate removed from $100 \mathrm{cc}$. of blood. In the remaining three experiments at this pressure no really significant discrepancy existed between the observed and calculated values. Had $8.0 \mathrm{cc}$. of capillary filtrate containing even 1 per cent of protein been filtered from blood with a plasma volume of 50 per cent, the discrepancy between observed and calculated protein should have been 0.16 per cent. This difference, if actually present, should have been detected, since the control analyses of protein (Experiments 13, 14, and 15) agreed within 0.02 to 0.06 per cent. The capillary filtrate produced at a venous pressure of $60 \mathrm{~mm}$. $\mathrm{Hg}$ contains, therefore, relatively little protein, averaging in four experiments 0.3 per cent.

The amount of fluid filtered from the blood by a venous pressure of $40 \mathrm{~mm}$. $\mathrm{Hg}$ is small in comparison with the combined errors of the hematocrit and protein determinations. While no loss of protein was to be detected, this finding is of no significance since, had the filtrate con- 
tained 3 per cent protein, the changes in two experiments, (numbers 10 and 12) at least, would have been barely outside the error of the method of protein determination. The apparent gain of protein observed at $40 \mathrm{~mm} . \mathrm{Hg}$ is probably to be explained on the basis of the relatively large errors involved. On this account, protein analyses were not carried out in the three observations in which venous pressure was only 20 $\mathrm{mm}$. Hg.

The loss of protein at $80 \mathrm{~mm}$. $\mathrm{Hg}$ is contrary to the interpretation of Plass and Rourke who concluded from similar experiments at 80,90 and $100 \mathrm{~mm} . \mathrm{Hg}$ that protein must pass into the blood from the asphyxiated tissue cells. This conclusion was based on their finding that the percentage increase in plasma protein was uniformly greater than the percentage decrease of plasma volume. This direct comparison of percentage changes is, however, not justified since changes in cell volume and plasma volume are computed as volumes per cent of whole blood, whereas protein content is expressed in terms of grams per $100 \mathrm{cc}$. of plasma. The situation can be made clear by considering the change in relative plasma volume and the change in plasma protein percentage which would occur if $10 \mathrm{cc}$. of protein free filtrate were removed from $100 \mathrm{cc}$. of blood with a plasma volume of 50 per cent. The relative plasma volume would be decreased from $50 / 100$, or 50 per cent, to $40 / 90$, or 44.4 per cent-a reduction amounting to 11 per cent of the original figure. The plasma proteins, however, would be concentrated in proportion to the change in absolute plasma volume. Thus, $50 \mathrm{cc}$. of plasma would be concentrated to $40 \mathrm{cc}$. and, without addition of protein, the plasma proteins would be increased by 25 per cent. Therefore, the observation that plasma volume decreases less than the protein content increases does not indicate that protein has been added to the blood.

The data reported by Plass and Rourke have been collected in Table 2 and recalculated. It may be noted that in every instance but one (Experiment 9) the calculated total protein percentage is significantly greater than the observed value, indicating loss of protein from the blood stream. At a venous pressure of $100 \mathrm{~mm}$. $\mathrm{Hg}$ the filtrate contained between 2.5 and 3.1 per cent protein. At a venous pressure of $90 \mathrm{~mm}$. Hg the filtrate in one instance apparently contained no protein, while in the other two instances the filtrate contained 2.5 and 2.2 per cent of protein. In one observation at $80 \mathrm{~mm}$. $\mathrm{Hg}$ the filtrate contained 1.6 per cent of protein.

One may conclude therefore that at venous pressures of $80 \mathrm{~mm} . \mathrm{Hg}$ or more the capillary wall becomes relatively permeable to protein. At a venous pressure of $60 \mathrm{~mm}$. $\mathrm{Hg}$ conspicuous loss of protein could not be detected. The capillary filtrate appeared in four instances to contain 0.7 per cent protein or less. 
TABLE 2

Data from Plass and Rourke (1927, page 737)

\begin{tabular}{|c|c|c|c|c|c|c|c|c|c|c|}
\hline \multirow{2}{*}{$\begin{array}{c}\text { Experi- } \\
\text { ment } \\
\text { number }\end{array}$} & \multicolumn{2}{|c|}{$\begin{array}{l}\text { Venous } \\
\text { congestion }\end{array}$} & \multirow{2}{*}{$\begin{array}{c}\text { Plasma } \\
\text { vol- } \\
\text { ume }\end{array}$} & \multirow{2}{*}{$\begin{array}{c}\text { Class } \\
\text { of data }\end{array}$} & \multirow{2}{*}{$\underset{\min }{\text { Albu- }}$} & \multirow{2}{*}{$\begin{array}{c}\text { Globu- } \\
\text { lin }\end{array}$} & \multirow{2}{*}{$\begin{array}{c}\text { Fibrino- } \\
\text { gen }\end{array}$} & \multirow{2}{*}{$\begin{array}{c}\text { Total } \\
\text { pro- } \\
\text { tein }\end{array}$} & \multirow{2}{*}{$\begin{array}{c}\text { Water } \\
\text { loss }\end{array}$} & \multirow{2}{*}{$\begin{array}{c}\text { Total } \\
\text { protein } \\
\text { in } \\
\text { filtrate }\end{array}$} \\
\hline & $\begin{array}{l}\text { Pres- } \\
\text { sure }\end{array}$ & Dura- & & & & & & & & \\
\hline 7 & $\begin{array}{r}\underset{H \boldsymbol{H}}{\operatorname{mm}} . \\
0 \\
100\end{array}$ & $\begin{array}{c}\underset{\min -}{\text { utes }} \\
15\end{array}$ & $\begin{array}{c}\text { per } \\
\text { cent } \\
62.3 \\
53.5\end{array}$ & $\begin{array}{l}\text { initial } \\
\text { observed } \\
\text { calculated }\end{array}$ & $\begin{array}{c}\text { grams } \\
\text { per } \\
100 \text { cc. } \\
4.85 \\
6.88 \\
6.96\end{array}$ & $\begin{array}{c}\text { grams } \\
\text { per } \\
100 \text { cc. } \\
2.50 \\
2.58 \\
3.59\end{array}$ & $\begin{array}{c}\text { grams } \\
\text { per } \\
100 \text { cc. } \\
0.24 \\
0.33 \\
0.34\end{array}$ & $\begin{array}{r}\text { grams } \\
\text { per } \\
100 \text { cc. } \\
7.59 \\
9.79 \\
10.89\end{array}$ & $\begin{array}{c}c c . \\
\text { per } \\
100 c c . \\
18.9\end{array}$ & $\begin{array}{l}\text { grams } \\
\text { per } \\
100 \mathrm{cc} .\end{array}$ \\
\hline 8 & $\begin{array}{r}0 \\
100\end{array}$ & 20 & $\begin{array}{l}61.1 \\
45.0\end{array}$ & $\begin{array}{l}\text { initial } \\
\text { observed } \\
\text { calculated }\end{array}$ & $\begin{array}{l}4.76 \\
7.70 \\
9.15\end{array}$ & $\begin{array}{l}2.47 \\
3.47 \\
4.74\end{array}$ & $\begin{array}{l}0.29 \\
0.45 \\
0.56\end{array}$ & $\begin{array}{r}7.52 \\
11.62 \\
14.45\end{array}$ & 29.3 & 3.1 \\
\hline 10 & $\begin{array}{r}0 \\
100\end{array}$ & 22 & $\begin{array}{l}57.8 \\
44.3\end{array}$ & $\begin{array}{l}\text { initial } \\
\text { observed } \\
\text { calculated }\end{array}$ & $\begin{array}{l}4.45 \\
6.48 \\
7.66\end{array}$ & $\begin{array}{l}2.27 \\
3.10 \\
3.90\end{array}$ & & $\begin{array}{r}6.72 \\
9.58 \\
11.56\end{array}$ & 24.2 & 2.8 \\
\hline 4 & $\begin{array}{r}0 \\
90\end{array}$ & 15 & $\begin{array}{l}62.3 \\
56.9\end{array}$ & $\begin{array}{l}\text { initial } \\
\text { observed } \\
\text { calculated }\end{array}$ & $\begin{array}{l}5.02 \\
5.79 \\
6.28\end{array}$ & $\begin{array}{l}2.27 \\
2.70 \\
2.84\end{array}$ & $\begin{array}{l}0.29 \\
0.38 \\
0.36\end{array}$ & $\begin{array}{l}7.58 \\
8.87 \\
9.48\end{array}$ & 12.5 & 2.5 \\
\hline 5 & $\begin{array}{r}0 \\
90\end{array}$ & 15 & $\begin{array}{l}55.1 \\
46.9\end{array}$ & $\begin{array}{l}\text { initial } \\
\text { observed } \\
\text { calculated }\end{array}$ & $\begin{array}{l}4.70 \\
6.09 \\
6.52\end{array}$ & $\begin{array}{l}2.16 \\
2.60 \\
3.00\end{array}$ & $\begin{array}{l}0.26 \\
0.34 \\
0.36\end{array}$ & $\begin{array}{l}7.12 \\
9.03 \\
9.88\end{array}$ & 15.4 & 2.2 \\
\hline 9 & $\begin{array}{r}0 \\
90\end{array}$ & 21 & $\begin{array}{l}55.6 \\
48.1\end{array}$ & $\begin{array}{l}\text { initial } \\
\text { observed } \\
\text { calculated }\end{array}$ & $\begin{array}{l}5.00 \\
6.76 \\
6.76\end{array}$ & $\begin{array}{l}2.31 \\
3.57 \\
3.13\end{array}$ & $\begin{array}{l}0.29 \\
0.37 \\
0.39\end{array}$ & $\begin{array}{r}7.60 \\
10.70 \\
10.28\end{array}$ & 14.5 & 0.0 \\
\hline 11 & $\begin{array}{r}0 \\
80\end{array}$ & 26 & $\begin{array}{l}65.0 \\
62.0\end{array}$ & $\begin{array}{l}\text { initial } \\
\text { observed } \\
\text { calculated }\end{array}$ & $\begin{array}{l}5.25 \\
5.66 \\
5.98\end{array}$ & $\begin{array}{l}2.51 \\
2.94 \\
2.86\end{array}$ & & $\begin{array}{l}7.76 \\
8.60 \\
8.84\end{array}$ & 7.9 & 1.6 \\
\hline
\end{tabular}

(C). The relative increase in globulin and albumin percentages produced by high grades of venous congestion

Since the globulin molecule is larger than the albumin molecule, venous congestion might be expected to increase the former fraction more than the latter. Table 3 shows a comparison of the percentage increase in the albumin and globulin (plus fibrinogen) fractions found in those experiments in which protein percentage changes were large enough to make the figures significant. In two instances, globulin (plus fibrinogen) was increased by a slightly greater amount than albumin, while in the other two instances the increases were about equal.

Plass and Rourke (1927) as well as Rowe (1915) found little regularity in the percentage increase of the various protein fractions of the plasma. In Table 2 the recalculated data of Plass and Rourke show in general 
that fibrinogen, albumin and globulin have been lost in the capillary filtrate. The calculated values for albumin exceed the observed values in every instance but one. In the case of globulin the calculated values exceed the observed in 4 of the 7 experiments. In the remainder the

TABLE 3

Experimental data on protein fractionation

\begin{tabular}{|c|c|c|c|c|c|}
\hline \multirow{2}{*}{$\begin{array}{l}\text { Experiment } \\
\text { number }\end{array}$} & \multirow{2}{*}{$\begin{array}{c}\text { Congestion } \\
\text { pressure }\end{array}$} & \multirow{2}{*}{ Globulin } & \multirow{2}{*}{ Albumin } & \multicolumn{2}{|c|}{ Percentage increase } \\
\hline & & & & Globulin & Albumin \\
\hline 2 & $\begin{array}{c}m m . \mathrm{Hg} \\
9 \\
80\end{array}$ & $\begin{array}{c}\text { grams per } \\
100 \text { cc. } \\
1.55 \\
2.15\end{array}$ & $\begin{array}{c}\text { grams per } \\
100 \text { cc. } \\
4.06 \\
5.20\end{array}$ & $\begin{array}{c}\text { per cent } \\
38.7\end{array}$ & $\begin{array}{c}\text { per cent } \\
27.9\end{array}$ \\
\hline 3 & $\begin{array}{r}9 \\
80\end{array}$ & $\begin{array}{l}2.25 \\
2.79\end{array}$ & $\begin{array}{l}4.24 \\
5.36\end{array}$ & 24.0 & 26.4 \\
\hline 4 & $\begin{array}{r}9 \\
80\end{array}$ & $\begin{array}{l}2.43 \\
3.02\end{array}$ & $\begin{array}{l}4.15 \\
4.79\end{array}$ & 24.3 & 15.4 \\
\hline 16 & $\begin{array}{r}9 \\
80\end{array}$ & $\begin{array}{l}2.77 \\
3.70\end{array}$ & $\begin{array}{l}4.04 \\
5.46\end{array}$ & 33.7 & 35.1 \\
\hline
\end{tabular}

observed value exceeds the calculated globulin percentage. In the case of fibrinogen the calculated and observed values agree surprisingly well in four of the five experiments. In one experiment the difference amounts to .09 per cent.

(D). The protein content of edema fluid accumulating in the tissue spaces during venous congestion

In order to amplify the observations on composition of the capillary filtrate produced during mild venous stasis, fluid was removed from the lower extremities of two patients who were suffering from edema. In Case 1, venous pressure in one leg had been raised to $30 \mathrm{~mm}$. $\mathrm{Hg}$ for a period of several days by an intra-abdominal metastatic neoplasm. Case 2 was suffering from nephrosis with generalized edema. The edema fluids in both instances contained relatively small amounts of protein.

Case 1, J. N., male, aged 46, was admitted to the University Hospital on September 11, 1931, complaining of weakness, nausea and anorexia. Examination showed a normal blood pressure, a marked secondary anemia, achlorhydria, a large epigastric mass and occult blood in the stools. The diagnosis of carcinoma of the stomach was verified by $\mathbf{x}$-ray and at laparotomy numerous metastases were found in the liver. He was discharged but returned to the hospital in December, 1931, with profound anemia and a still larger epigastric mass. During the two periods spent in the hospital five transfusions, 
each of 500 cc. of citrated blood, were given. On December 21, following the last transfusion, slight edema of both ankles appeared. There was no evidence of cardiac or renal disease. The plasma protein percentage was still normal, 6.64 per cent, owing, no doubt, to the transfusions which had prevented the decrease usual in the malnutrition of gastric neoplasm. The osmotic pressure of the plasma proteins was measured and found to be $34.0 \mathrm{~cm}$. water.

Seven days after the onset of the slight bilateral edema the fluid accumulation in the left leg increased rapidly, extending finally to the genitalia. At this time the patient complained of pain in the left calf. On examination the veins of the left leg were slightly but definitely engorged and the skin of the left foot was somewhat cyanotic in tint. Venous pressure was measured in a vein over the patella of each leg by means of a celluloid capsule (Krogh, Turner and Landis (1932)). In the recumbent position the venous pressure in the conspicuously edematous left leg was $30 \mathrm{~mm} . \mathrm{Hg}$, in the very slightly edematous right leg, $10 \mathrm{~mm}$. Hg. Both legs were exposed to the air (temperature $24.0^{\circ}$ C.) and skin temperature was measured over the instep by means of a thermal junction. The temperature of the left leg fell more rapidly than that of the right and remained finally 2.4 degrees cooler, indicating diminished circulation on the left side.

A single Southey's tube was inserted into the external aspect of the left leg above the ankle and approximately $40 \mathrm{cc}$. of edema fluid were removed. The fluid was clear, slightly yellowish in color and did not coagulate. The first few cc. of edema fluid contained 0.39 per cent of protein. A second determination, made on the fluid obtained about one hour later, showed the same protein percentage.

Case 2, E. McD., male, aged 21, was admitted to the University Hospital for the first time in May, 1929, suffering from a bloody diarrhea which had existed intermittently for ten years. The diagnosis of chronic ulcerative colitis was made at this time. He was treated in the hospital for six weeks with improvement. Following discharge he had alternating periods of improvement and regression, finally returning to the hospital November 10,1931, complaining chiefly of "dropsy" and fatigue. On examination the patient showed marked pitting edema of both legs, ascites and right pleural effusion. The blood pressure was $140 / 80$ and the urine contained on numerous occasions a cloud of albumin with many hyaline casts. Doubly refractile lipoid bodies were present. The serum proteins were 3.56 per cent and the albumin-globulin ratio was 0.86 . Blood cholesterol was $333 \mathrm{mgm}$. per $100 \mathrm{cc}$. The diagnosis at this time was chronic ulcerative colitis, lipoid nephrosis. The edema proved resistant to the usual diuretic therapy which was handicapped by the patient's gastro-intestinal symptoms. It was decided to use Southey's tubes.

Six hours prior to their insertion the patient was seated in a chair with legs dependent. In this position the hydrostatic pressure of the column of blood in the veins amounted to $40 \mathrm{~mm}$. Hg. The edema of the legs, moderate in the recumbent position, increased rapidly, with the change in posture. In the course of 30 hours, $6,500 \mathrm{cc}$. of fluid were withdrawn. The protein content of this fluid was 0.09 per cent while the plasma proteins examined simultaneously were 3.27 per cent.

\section{DISCUSSION}

It was the purpose of these studies to measure by another method the effect of graded venous congestion on the movement of fluid from the blood to the tissue spaces. In contrast to the earlier findings of 
Mende (1919), plethysmographic studies (Krogh, Landis and Turner (1932)) indicated that a relatively small rise in venous pressure was sufficient to cause small, but definitely measurable, amounts of fluid to accumulate in the tissues. This conclusion has been verified by the present studies, in that a venous pressure of $20 \mathrm{~mm}$. $\mathrm{Hg}$ was accompanied in two instances by a slight but measurable loss of fluid from the blood stream.

The plethysmographic and the blood studies agree also in indicating an increasing rate of fluid filtration with increase in venous pressure. A straight line relationship was observed between venous pressure and filtration rate when the latter was measured by plethysmograph during venous congestion of 11 to $39 \mathrm{~mm}$. $\mathrm{Hg}$ (15 to $50 \mathrm{~cm}$. water). This relationship is not found when fluid loss from the blood is charted against the higher venous pressures used in the present studies. Blood flow, however, will be decreased particularly with the higher grades of venous congestion. Filtration at a given rate will concentrate the blood more when the rate of flow is simultaneously decreased. This factor was not of great importance in the plethysmographic studies in which the fluid filtration itself was measured at relatively low pressures. With venous pressures nearer diastolic arterial pressure the diminution of the blood flow is quite considerable (G. N. Stewart (1912-13)) and this must increase to some extent the loss of fluid from any given volume of blood. Moreover, with the highest venous congestion $(80 \mathrm{~mm} . \mathrm{Hg})$ there appears to be a measurable loss of protein through the capillary wall which must also facilitate the loss of fluid from the blood.

In explaining the movement of fluid through the capillary wall into the tissue spaces, the capillary endothelium has been regarded as relatively impermeable to the plasma proteins. Drinker and his co-workers have called attention to the high protein content of lymph which may rise to 4.5 per cent (Drinker and Field (1931)). Loewen, Field and Drinker (1931) conclude that the effective osmotic pressure for returning water to the blood capillaries is the difference between the colloid osmotic pressure of the blood and the lymph from the area under observation. Yet during the venous obstruction produced by tying all the veins of an extremity of a dog (Field and Drinker, 1931) the amount of lymph produced was increased while the protein content diminished. In plasmapheresis experiments also the more rapid flow of lymph 'was accompanied by a smaller protein content. Attention has been called (Krogh, Landis and Turner (1932)) to the probability that the protein in lymph varies widely depending, among other things, on the rate of filtration and the relative amount of absorption. The slower the filtration and the more complete the reabsorption, the more will the composition of lymph differ from that of the capillary filtrate and hence from that of average tissue fluid. The more rapid the filtration (as in venous congestion and in plasmapheresis) the more nearly will both average tissue fluid 
and lymph resemble the fluid filtered through the capillary wall. The fact that the more rapid lymph production in venous congestion was accompanied by decrease in protein content indicates that the previously existing difference between capillary filtrate and lymph was being reduced. It does not seem justifiable to state that the effective osmotic pressure for returning water to the blood capillaries is the difference between the colloid osmotic pressure of the blood and the lymph from the area under observation. Actually, lymph represents tissue fluid after the absorption process has been carried to as complete a stage as conditions in the blood stream permit.

Field and Drinker (1931) found that when all the veins to a limb were ligated the protein content of lymph did not fall below 1 per cent. The stasis produced by this procedure is of extreme grade, and is apparently accompanied by the passage of protein and red cells through the capillary wall.

When the effects of graded degrees of venous congestion are studied in man a loss of protein through the capillary wall is easily detected with venous pressures of 80,90 and $100 \mathrm{~mm}$. $\mathrm{Hg}$. The suggestion of Plass and Rourke that protein under these conditions moved from the tissue cells, to lymph and then into the blood stream has already been discussed.

At congestion pressures of $60 \mathrm{~mm} . \mathrm{Hg}$ the loss of protein was very much less and, except in one instance, too small to be detected in plasma protein analyses. It is believed that the findings at $60 \mathrm{~mm} . \mathrm{Hg}$ are significant but it is obvious that at $40 \mathrm{~mm}$. $\mathrm{Hg}$ the changes in blood volume are too small to permit any conclusion concerning the protein content of the capillary filtrate.

The tissue fluid obtained from two cases of edema during venous stasis indicates that the protein in the capillary filtrate $(0.39$ and 0.09 per cent) may be very much less than the protein content usually described for normal lymph. It is, therefore, not justifiable to assume that lymph represents the capillary filtrate nor even average tissue fluid unless absorption is completely avoided.

Nothing can be said concerning the mechanism by which the protein passes through the capillary wall at high congestion pressures. The presence of red cells in lymph (Field and Drinker) and petechiae frequently noted in the skin (Plass and Rourke) suggest mechanical rupture of the capillary wall. The fact that lymph protein in general decreases during such congestion in spite of the presence of red cells does not rule out mechanical rupture, since the cells and plasma escaping through a few weak places in the wall may be diluted by a relatively protein free filtrate from the remainder of the capillary. Anoxemia, which has been observed to change capillary permeability (Landis, (1928)), may also be a factor at high venous pressures. 
The findings indicate that the permeability of the capillary wall with respect to protein varies with the grade of venous congestion. Caution must be used in extending conclusions based on observations involving high grades of venous congestion to considerations of normal capillary permeability.

\section{SUMMARY}

Blood samples removed from the arm veins during graded congestion were compared in order to measure the filtration of fluid resulting from the increased venous pressure. The loss of protein through the capillary wall was estimated at venous pressures of 80,60 and $40 \mathrm{~mm}$. $\mathrm{Hg}$.

Comparison of hemoglobin readings and red cell counts showed that during venous congestion the fluid is lost chiefly from the plasma.

The loss of fluid could be detected at venous pressures as low as 20 $\mathrm{mm} . \mathrm{Hg}$ and amounted to between 0.0 and $2.3 \mathrm{cc}$. per $100 \mathrm{cc}$. of blood.

The amount of fluid lost from the blood was conspicuously greater at higher venous pressures; venous congestion of $80 \mathrm{~mm}$. Hg filtered as much as $19.5 \mathrm{cc}$. per $100 \mathrm{cc}$. of blood.

At a venous pressure of $80 \mathrm{~mm}$. $\mathrm{Hg}$ protein was lost from the blood plasma in an amount indicating that the capillary filtrate contained an average of 1.5 per cent of protein. At a venous pressure of $60 \mathrm{~mm} . \mathrm{Hg}$ very little protein loss could be detected and the capillary filtrate contained an average of 0.3 per cent protein.

Two cases of edema are described in which edema fluid was collected during venous congestion. The protein content of the edema fluid was 0.39 and 0.09 per cent, indicating that the capillary wall retained approximately 95 per cent of the plasma protein.

\section{BIBLIOGRAPHY}

Dautrebande, L., Davies, H. W., and Meakins, J., Heart, 1923, x, 133. The Influence of Circulatory Changes on the Gaseous Exchanges of the Blood. III. An Experimental Study of Circulatory Stasis.

Dreyer, G., Bazett, H. C., and Pearce, H. F., Lancet, 1920, ii, 588. Diurnal Variations in the Hemoglobin Content of the Blood.

Drinker, C. K., and Field, M. E., Am. J. Physiol., 1931, xcvii, 32. The Protein Content of Mammalian Lymph and the Relation of Lymph to Tissue Fluid.

Drury, A. N., and Jones, N. W., Heart, 1927, xiv, 55. Observations upon the Rate at Which Oedema Forms When the Veins of the Human Limb are Congested.

Eisenman, A. J., Bulger, H. A., and Peters, J. P., J. Biol. Chem., 1926, lxvii, 159. Total Acid-Base Equilibrium of Plasma in Health and Disease. II. The Effect of $\mathrm{CO}_{2}$ Tension on the Concentration of the Acids of the Plasma of Oxygenated Blood.

Field, M. E., and Drinker, C. K., Am. J. Physiol., 1931, xcviii, 378. The Rapidity of Interchanges Between the Blood and Lymph in the Dog.

Howe, P. E., J. Biol. Chem., 1921, xlix, 109. The Determination of Proteins in Blood-A Micro Method. 
Krogh, A., The Anatomy and Physiology of Capillaries. Yale University Press, New Haven, 1929, revised edition.

Krogh, A., Landis, E. M., and Turner, A. H., J. Clin. Invest., 1932, xi, 63. The Movement of Fluid through the Human Capillary Wall in Relation to Venous Pressure and to the Colloid Osmotic Pressure of the Blood.

Krogh, A., Turner, A. H., and Landis, E. M., J. Clin. Invest., 1932, xi, 357. A Celluloid Capsule for Measuring Venous Pressures.

Lamson, P. D., Abt, A. F., Oosthuisen, C. A., and Rosenthal, S. M., J. Pharm. and Exp. Therap., 1923, xxi, 401. The Influence of the Arterial Blood Supply to the Liver on Hemoglobin Concentration in Certain Acute Conditions.

Landis, E. M., Am. J. Physiol., 1928, lxxxiii, 528. Micro-injection Studies of Capillary Permeability. III. The Effect of Lack of Oxygen on the Permeability of the Capillary Wall to Fluid and to the Plasma Proteins.

Loewen, D. F., Field, M. E., and Drinker, C. K., Am. J. Physiol., 1931, xcviii, 70. The Colloid Osmotic Pressure of Dog Blood and Lymph.

Mende, D., Deutsche Ztschr. f. Chir., 1919, cl, 379. Über Hyperämie und Ödem bei der Hemmung des Rückflusses des venösen Blutes durch die Staubinde.

Peters, J. P., Trans. Assoc. Am. Physicians, 1924, xxxix, 63. The Effect of the Tissues on the Respiratory Functions of the Blood.

Peters, J. P., Eisenman, A. J., and Bulger, H. A., J. Clin. Invest., 1925, i, 435. The Plasma Proteins in Relation to Blood Hydration. I. In Normal Individuals and in Miscellaneous Conditions.

Plass, E. D., and Rourke, M. D., J. Lab. and Clin. Med., 1927, xii, 735. The Effect of Venous Stasis on the Proteins of Blood Plasma and on the Rate of Sedimentation of the Red Blood Corpuscles.

Rowe, A. H., J. Lab. and Clin. Med., 1915, i, 485. The Effect of Venous Stasis on the Proteins of Human Blood Serum.

Schultz, W., and Wagner, G., Fol. Serol., 1909, iii, 387. Über den Flüssigkeitsaustausch zwischen Blut und Geweben unter der Einwirkung von thermischen und anderen Einflüssen.

Stewart, G. N., Studies on the Circulation in Man. Harvey Lectures, 1912$13,86$.

Thompson, W. O., Thompson, P. K., and Dailey, M. E., J. Clin. Invest., 1928, $v, 573$. The Effect of Posture upon the Composition and Volume of the Blood in Man.

Van Slyke, D. D., Wu, H., and McLean, F. C., J. Biol. Chem., 1923, Ivi, 765. Studies of Gas and Electrolyte Equilibria in the Blood. V. Factors Controlling the Electrolyte and Water Distribution in the Blood.

Waterfield, R. L., J. Physiol., 1931, 1xxii, 110. The Effects of Posture on the Circulating Blood Volume. 